Dinamika Kesehatan Jurnal Kebidanan dan Keperawatan Vol 11 No. 1 Juli 2020 ( ISSN: 2086-3454 EISSN: 2549-4058)

url: http://ojs.dinamikakesehatan.unism.ac.id DOI : https://doi.org/10.33859/dksm.v1lil

Pengendalian Kualitas Kesehatan dalam Upaya Penanggulangan Gizi Buruk pada Balita: Literatur Review

\title{
Pengendalian Kualitas Kesehatan dalam Upaya Penanggulangan Gizi Buruk pada Balita: Literatur Review
}

\author{
Ilmiati1, Jamhary2, Rianti Indah Lestari3 \\ 123 Program Studi Teknik Industri Universitas Sari Mulia \\ *correspondence author: Telepon: 0511-3268105, Fax: 0511-3270134, E-mail: \\ ilmiati201@gmail.com
}

DOI: $10.33859 / \mathrm{dksm.v11i1.609}$

\begin{abstract}
Abstrak
Latar belakang: Gizi buruk pada balita merupakan salah satu permasalahan serius yang terjadi di Indonesia. Kurangnya pengetahuan tentang gizi buruk, keterbatasan sarana prasarana yang mendukung, serta peran kolaborasi lintas profesi yang belum optimal merupakan faktor-faktor penyebab belum tercapainya upaya penanganan kesehatan khususnya pada penanggulangan gizi buruk serta pengendalian kualitas yang masih terbatas pada implementasi.

Tujuan: Penelitian ini bertujuan untuk mengidentifikasi faktor-faktor penyebab permasalahan gizi buruk di Indonesia serta memberikan rekomendasi dalam penanganan gizi buruk secara berkelanjutan.
\end{abstract}

Metode: Studi literatur digunakan dalam menelaah permasalahan tentang gizi buruk

Hasil: Rekomendasi berupa tools yang relevan untuk pengendalian kualitas kesehatan

Kata Kunci: Gizi buruk balita, Faktor penyebab, Tools pengendalian kualitas kesehatan 


\section{Abstract}

Background Malnutrition in children is one of the serious problem that occurs in Indonesia. Lack of knowledge about malnutrition, Limited of support infrastructure, and The Inter-professional collaboration is not optimal, are factors that the prevention of malnutrition has not achieved. Moreover, the quality control which is still limited to implementation.

Objective The purpose of this study was to identify the factors that causes malnutrition problems in Indonesia and provide recommendation about managing of malnutrition sustainability.

Methods Some of literature review are used in examining problems regarding malnutrition

Results Recommendation of a relevant tools for quality control of healthcare

Key Words Malnutrition in children, Cause of factors, Quality control of healthcare tools

\section{Pendahuluan}

Salah satu indikator keberhasilan dalam membangun suatu bangsa dipengaruhi oleh kualitas sumber daya manusianya, dimana tidak terlepas dari makanan apa yang dikonsumsi sehingga tercukupi gizi yang diperlukan oleh tubuh. Saat ini, Indonesia dihadapkan pada empat permasalahan gizi utama yang meliputi kurangnya konsumsi energi dan protein, kekurangan vitamin A, anemia gizi besi, dan kekurangan yodium (Ismail dkk, 2016). Kasus gizi buruk masih menjadi permasalahan serius khususnya di Indonesia dimana seringkali terjadi pada kelompok anak usia di bawah lima tahun. Gizi buruk merupakan suatu kondisi di mana seseorang dinyatakan kekurangan nutrisi atau status nutrisinya berada di bawah standar ratarata. Adapun nutrisi yang dimaksud adalah berupa protein, karbohidrat, dan kalori. (Departemen kesehatan, 2003 dalam Murwati dan Devianti, 2016).

Faktor-faktor yang mempengaruhi terjadinya gizi buruk diantaranya yaitu status sosial ekonomi, ketidaktahuan ibu tentang pemberian gizi yang baik untuk anak dan Berat Badan Lahir Rendah (BBLR) (Kusriadi, 2010; Anwar dkk, 2010 dalam Murwati dan Devianti, 2016). Selain itu asupan makanan keluarga, faktor infeksi, dan pendidikan ibu menjadi penyebab kasus gizi buruk (Razak dkk, 2011 dalam Murwati dan Devianti, 2016). Faktorfaktor ini seiring dengan penelitian yang telah dilakukan oleh Anwar dkk (2011), dimana penelitian di Kabupaten Lombok Timur menunjukkan bahwa terdapat hubungan status ekonomi, pendidikan ibu, pengetahuan ibu dalam monitoring pertumbuhan, perhatian dari 
ibu, pemberian ASI, kelengkapan imunisasi, dan asupan makanan balita dengan kejadian gizi buruk.

Gizi buruk jika tidak diatasi dan dilakukan penanganan maka akan berdampak pada kematian dan infeksi kronis (Soetjiningsih, 2000 dalam Murwati dan Devianti, 2016).

Oleh karena itu penurunan angka gizi buruk dari $8,5 \%$ menjadi $5 \%$ serta perawatan $100 \%$ terhadap penderita gizi buruk merupakan salah satu program pemerintah yang tertuang dalam Rencana Pembangunan Jangka Menengah Nasional (RPJMN) tahun 2005-2009 tentang upaya penurunan kasus gizi buruk. Program ini juga selaras dengan indikator keluaran dalam Rencana Strategis Kementerian Kesehatan tahun 2010-2014.

Adapun ruang lingkup dalam upaya penanggulangan gizi buruk pada balita dari tingkat kabupaten, kota, dan kecamatan sampai tingkat rumah tangga meliputi prosedur penjaringan kasus balita dengan dengan gizi buruk, prosedur pelayanan balita gizi buruk puskesmas, prosedur pelacakan balita gizi buruk dengan cara investigasi, prosedur pelayanan balita gizi buruk di rumah tangga, prosedur koordinasi lintas sektoral dalam upaya penanggulangan gizi buruk

\section{Literatur Review}

Salah satu upaya untuk meningkatkan berat badan pada penderita gizi buruk yaitu dengan pemberian diet Formula 100. Pemberian Formula 100 diberikan pada fase transisi dan rehabilitasi, dengan tujuan mengejar ketinggalan berta badan yang dialami, atau dengan kata lain untuk mencapai berat badan normal sesuai dengan panjang badan serta tahap perkembangan kepandaian dan aktivitas motoriknya (duduk, merangkak, berdiri, berjalan, berlari) berkembang sesuai dengan umurnya (Kementerian Kesehatan, 2011 dalam Murwati dan Devianti, 2016). Dalam penelitian yang dilakukan oleh Murwati dan Devianti (2011), sejumlah kasus gizi buruk ditemukan di Kabupaten Sukoharjo dari tahun ke tahun terutama pada akhir Desember 2013 sampai Januari 2014. Data dari Dinas Kesehatan Kabupaten Sukoharjo menunjukkan bahwa dari 4109 balita, sebanyak 32 balita diantaranya teridentifikasi mengalami gizi buruk. Oleh karena itu puskesmas yang berkoordinasi dengan dinas kesehatan setempat berupaya melaksanakan program yang bertujuan untuk meningkatkan pelayanan kesejahteraan keluarga dengan cara meningkatkan status gizi buruk pada balita yaitu dengan pemberian formula 100 selama dua bulan. Formula 100 terdiri dari campuran susu krim, skim, gula, minyak sayur, dan 
larutan elektrolit yang diencerkan dengan air hangat sedikit demi sedikit sambil diaduk sampai homogen dan volume menjadi 1000 $\mathrm{ml}$, dan dapat langsung diminum atau dimasak terlebih dahulu selama 4 menit. Pemberian formula ini dimaksudkan untuk mengetahui pengaruhnya terhadap status gizi balita.

Upaya penanggulangan gizi buruk juga telah dilakukan oleh Ismail dkk (2011) dalam penelitiannya di puskesmas Kota Sorong, Provinsi Papua Barat. Pada tahun 2007 berdasarkan Hasil Riset Kesehatan Dasar (RISKESDAS), terdapat penurunan jumlah gizi buruk sebesar 5,4\% dan gizi kurang sebesar 13\%. Sedangkan di tahun 2010 terjadi penurunan prevalensi gizi buruk menjadi 4,9\% sedangkan gizi kurang masih berada pada porsi $13 \%$. Pada dasarnya ambang batas prevalensi gizi buruk berada pada batas 5\% sesuai dengan angka prevalensi nasional. Namun terdapat 18 Provinsi dari total 33 Provinsi di Indonesia, prevalensi gizi buruknya masih berada di atas ambang batas yang telah ditentukan termasuk diataranya Provinsi Papua Barat. Dalam penelitian ini bertujuan untuk mengetahui implementasi terhadap program penanggulangan gizi buruk di 5 puskesmas yang terletak di wilayah kerja Dinas Kesehatan Kota Sorong. Berdasarkan laporan Dinas Kesehatan Kota Sorong menunjukkan bahwa prevalensi balita gizi buruk tahun 2008 sebesar
3,59\% dan menurun pada tahun 2009 sebesar $1,1 \%$, sementara tahun 2010 terjadi peningkatan sebesar 1,9\% seperti pada Gambar 1. di bawah ini

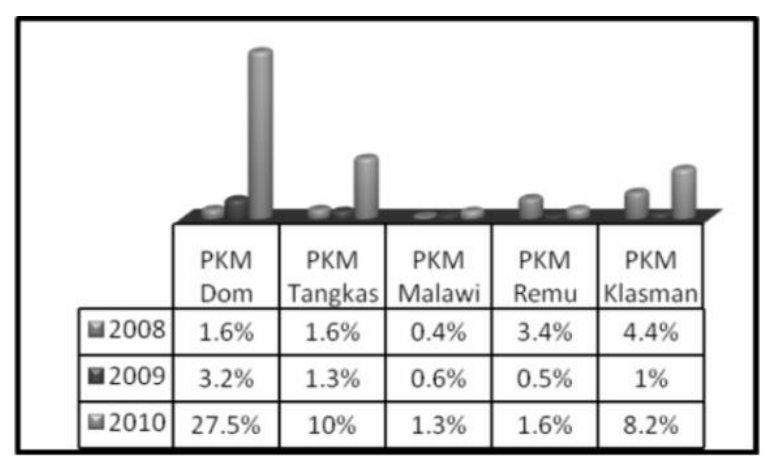

Gambar 1. Prevalensi Gizi Buruk DKK Kota Sorong

Berdasarkan Gambar 1, menunjukkan adanya perbedaan data yang sangat siginifikan antara Puskesmas Dom, Tangkas, dan Klasman disbanding Puskesmas Remu dan Malawi tentang prevalensi gizi buruk balita. Hal ini didasari dari penentuan status balita gizi buruk dimana Puskesmas Dom, Tangkas, dan Klasman menggunakan rumus $\mathrm{BB} / \mathrm{U}$ sedangkan 2 puskesmas lainnya menggunakan rumus $\mathrm{BB} / \mathrm{TB}$.

\section{Penelitian tentang penanggulangan gizi} buruk juga telah dilakukan oleh Risnah dkk (2018), dimana penelitian bertujuan untuk mengetahui pengaruh pelatihan pada petugas kesehatan terhadap pengetahuan tentang gizi buruk serta perlunya kolaborasi lintas profesi kesehatan. Adapun kolaborasi inter professional berdampak pada kepuasan pasien, mengurangi ketidakpastian, dan meningkatkan 
manajemen nyeri (Rodriguez, 2008 dalam Risnah dkk, 2018). Selain itu praktek kolaborasi inter professional sangat penting untuk perbaikan hasil pelayanan kesehatanpada pasien/ klien dan keluarga (Bainbridge dkk, 2010 dalam Risnah dkk, 2018). Status gizi buruk merupakan salah satu masalah kesehatan yang kompleks dimana berdampak pada pertumbuhan dan perkembangan seorang anak. Sehingga upaya untuk mengatasi masalah gizi diperlukan aksi lintas sektoral (Unicef, 2012 dalam Risnah dkk, 2018). Banyak faktor yang mempengaruhi status gizi anak salah satunya adalah pola pemberian ASI dan MPASI. Walaupun belum ditemukan korelasi antara kadar kalsium dalam ASI, PASI, dan MPASI dalam intake bayi dengan panjang badan bayi usia 6-12 bulan (Susanty dkk, 2012; Febria dkk, 2018 dalam Risnah dkk, 2018). Penelitian ini dilaksanakan di Kabupaten Jeneponto dimana berdasarkan data dari Sul-Sel DKp (2015) dan Departemen Kesehatan Jeneponto (2015) terdapat gambaran tentang status gizi balita yang didasarkan pada indeks $\mathrm{BB} / \mathrm{U}$ di atas target MDGs sebesar 15,5\% bahwa diperoleh lima kabupaten dengan persentase tinggi gabungan gizi buruk dan gizi kurang yaitu Pangkep 31,7\%, Maros 31\%, Takalar 29,6\%, Makasar 29,6\%, dan Jeneponto 28,4\%. Oleh karena itu, perlunya kerjasama lintas sektoral menjadi salah satu kunci utama bagi suksesnya pembangunan kesehatan khususnya penanggulangan masalah gizi pada anak.

\section{Metode}

Beberapa metode telah digunakan untuk mengendalikan kualitas kesehatan khususnya dalam penanganan gizi buruk pada balita. Penelitian yang telah dilakukan oleh Murwati dan Devianti (2016) dimana dilakukan pemberian formula 100 selama dua bulan di wilayah kerja puskesmas Sukoharjo. Metode yang digunakan dalam penelitian ini adalah pra eksperiment dengan rancangan one group pre test post test design. Penelitian dilaksanakan selama bulan Januari-Juni 2014. Untuk menentukan jumlah balita yang akan dilakukan pemberian formula 100 digunakan teknik purposive sampling. Adapun pemberian formula 100 dilakukan pada bulan April-Mei 2014 terhadap 26 balita gizi buruk.

Pada penelitian yang dilakukan oleh Ismail dkk (2016) ditemukan adanya miskomunikasi antara petugas dengan kepala puskesmas tentang pemberian makanan tambahan untuk balita secara rutin setiap bulan selama 3-4 bulan. Ini mengakibatkan terjadinya kesalahan dalam pelaporan hasil program gizi buruk antara petugas pelaksana dan kepala puskesmas. Metode yang digunakan dalam penelitian ini adalah 
rancangan kualitatif yang disajikan secara deskriptif eksploratif yaitu melalui observasi dan wawancara. Pendekatan dalm pengumpulan data dilakukan secara crosssectional dimana dilakukan pengambilan data terhadap petugas gizi di puskesmas sebagai informan utama serta kepala seksi gizi sebagai informan triangulasi. Metode pengumpulan data dilakukan dengan wawancara mendalam (indepth interview) dan observasi dilakukan dalam bentuk checklist khususnya tentang sarana dan prasarana serta tatalaksana pada balita gizi buruk.

Perlunya penelitian tentang kolaborasi lintas sektor sehingga diharapkan mampu mengubah kompetensi kolaborasi tentang pendidikan kesehatan untuk menanggulangi masalah gizi buruk pada balita. Adapun penelitian yang telah dilakukan oleh Risnah dkk (2018) merupakan penelitian deskriptif yang menggunakan mix method (kualitatif dan kuantitatif) dimana bertujuan untuk mengetahui pengaruh pelatihan terhadap pengetahuan tentang kolaborasi lintas profesi kesehatan pada penanganan kasus gizi buruk. Penelitian ini dilaksanakan di puskesmas Binamu Kota Kabupaten Jeneponto pada tanggal 5-6 Desember 2017. Sasaran dalam penelitian ini adalah seluruh petugas kesehatan yang bertugas di puskesmas Jeneponto. Responden yang bertugas sebagai informan digunakan sebanyak 12 orang yang didapatkan dengan teknik stratified random sampling. Pengumpulan data dilakukan dengan dua cara yaitu data primer melalui pengisian kuisioner, wawancara mendalam dengan informan dan observasi, sedangkan data sekunder berupa profil puskesmas, jumlah petugas kesehatan dan data lainnya yang diperlukan. Untuk data kualitatif digunakan analisis conten dan matriks pernyataan informan dilakukan dengan perbandingan data kualitatif yang telah diolah.

\section{Hasil dan Pembahasan}

Pengukuran yang telah dilakukan oleh Murwati dan Devianti (2016) dalam penelitiannya, didapatkan hasil bahwa terjadi peningkatan sebelum pemberian formula 100 dan sesudah pemberian formula 100 . Pemberian formula 100 selama 2 bulan diperoleh status gizi responden yaitu gizi buruk sebanyak $69 \%$, status gizi baik $26,9 \%$, dan status gizi buruk hanya 1 balita yaitu 3,8\%. Selain itu terdapat perbedaan berat badan sebelum dan sesudah pemberian formula 100 dari rata-rata $8,8 \mathrm{~kg}$ menjadi $10 \mathrm{~kg}$.

Permasalahan yang ditemukan saat pelaksanaan program penanganan kesehatan khususnya dalam penanggulangan gizi buruk dihasilkan pada penelitian Ismail dkk (2016). Beberapa faktor penyebab diantaranya: 
1. Kurangnya sosialisasi antar stakeholder yang terlibat dalam program tersebut

2. Faktor sumber daya seperti kurangnya pelatihan untuk pelaksana kegiatan, pendanaan yang belum dikelola dengan baik, serta sarana prasarana yang belum memadai

3. Kurangnya transparansi dan sosialisasi program menyebabkan petugas masih kurang memahami sehingga timbul sikap acuh dalam menjalankan program serta anggapan bahwa program hanya sekedar rutinitas, dengan alasan yang penting program dapat berjalan tanpa adanya evaluasi.

4. Struktur birokrasi yang belum jelas seperti tidak ada surat keputusan terhadap proses pelimpahan wewenang kepada pelaksana; kegiatan supervisi yang belum optimal karena tidak terencana, terkoordinasi, dan tidak terjadwal dengan baik; serta kurangnya Standar Operational Procedure (SOP).

Terlaksananya program dengan baik diperlukan kolaborasi lintas profesi seperti penelitian yang dilakukan oleh Risnah dkk (2018). Pada penelitian tersebut dilakukan pelatihan kolaborasi lintas profesi dengan menggunakan uji modul sebelum dan sesudah pelaksanaan. Namun tidak adanya perubahan pengetahuan stakeholder setelah dilakukan pelatihan menjadi permasalahan belum optimalnya penanggulangan gizi buruk. Walaupun begitu pelaksanaan pelatihan setidaknya mampu memberikan perubahan pengetahuan tentang pentingnya kolaborasi lintas profesi sebagai tujuan utama dari pelatihan.

\section{Simpulan, Keterbatasan, dan Rekomendasi}

Berdasarkan penelitian yang telah diulas di atas maka dapat disimpulkan bahwa pelaksanaan penanggulangan gizi buruk sudah dilakukan dengan baik oleh para peneliti. Dengan penggunaan metode-metode pengukuran kualitas kesehatan, maka tujuan yang diharapkan peneliti dapat tercapai. Meskipun demikian, reviewer menemukan beberapa keterbatasan dari masing-masing penelitian yaitu penelitian masih terbatas pada level action atau implementasi. Beberapa diantaranya telah melakukan proses evaluasi namun belum sampai kepada tahapan improvement atau proses perbaikan dan pelaksanaan secara berkelanjutan. Perlunya rekomendasi pengendalian kualitas kesehatan dengan penerapan tools yang relevan sehingga dapat mendukung ketercapaian pelaksanaan penanganan kesehatan khususnya dalam penanggulangan gizi buruk pada balita. Beberapa tools yang dapat digunakan untuk memudahkan pengukuran kualitas pada level improvement yaitu Control chart, Failure Mode Effects Analysis (FMEA), Pareto chart, Run chart, Continuous Quality Improvement 
(CQI), Total Quality Management (TQM), dan alat control lainnya.

\section{Daftar Pustaka}

Anwar, K., Juffrie, M., Julia, M. 2011. Faktor Risiko Kejadian Gizi Buruk di Kabupaten Lombok Timur, Propinsi Nusa Tenggara Barat. Jurnal Gizi Klinik Indonesia, 2(3). Retreived 14 Desember 2011 from:http://ijen.or.id/v2/content/vie w/33/40/

Bainbridge et. al. 2010. Competencies for Inter-Professional Collaboration. Journal of Physical Therapy Education. 24(1): 6

Buku Bagan Tatalaksana Gizi Buruk, Buku I. 2006. Jakarta

Departemen Kesehatan RI. 2003. Pedoman Penyuluhan Gizi Dan Kesehatan Dalam Penatalaksanaan Balita Gizi Buruk Secara Rawat Jalan Untuk Puskesmas. Jakarta.

Depkes. RI. 2009. Buku Pemantauan Tatalaksana Anak Gizi Buruk. Jakarta

Dinas Kesehatan Kota Sorong. 2008. Profil Dinas Kesehatan Kota Sorong. Provinsi Papua Barat

Ismail, Z., Kartasurya, I.M., Mawarni, A. 2016. Analisis Implementasi Program Penanggulangan Gizi Buruk Di Puskesmas Wilayah Kerja Dinas Kesehatan Kota Sorong Provinsi Papua Barat. Jurnal Manajemen Kesehatan Indonesia. 4(1):20-26.
Kemenkes RI. 2011. Pedoman pelayanan gizi buruk. Departemen Kesehatan RI: Jakarta.

Kesehatan RI. 2010. Riset Kesehatan Dasar. Badan Penelitian dan Pengembangan Kesehatan

Kusriadi. 2010. Analisis Faktor Risiko Yang Mempengaruhi Kejadian Kurang Gizi Pada Anak Balita Di Provinsi Nusa Tenggara Barat (NTB) [Karya Tulis Ilmiah].Bogor: Institut Pertanian Bogor.

Laporan Hasil Riset Kesehatan Dasar (RISKESDAS) Indonesia. 2007. Jakarta

Murwati., Devianti, T. 2016. Peningkatan Status Gizi Balita Dengan Gizi Buruk Melalui Pemberian Formula 100. Jurnal Kebidanan Dan Kesehatan Tradisional. 1(1):1-99.

Razak, A.A., Gunawan, I.M.A., Budiningsari, R.D. 2009. Pola Asuh Ibu Sebagai Faktor Risiko Kejadian Kurang Energi Protein (KEP) Pada Anak Balita. Jurnal Gizi Klinik Indonesia, 6(2). Retreived 14 Desember 2011 from:

http://www.ilib.ugm.ac.id/jurnal/do wnload. php? dataId=10761.

Risnah., Rosmah., Mustamin., Sofingi, I. 2018. Pengaruh Pelatihan Terhadap Pengetahuan Tentang Gizi Buruk Dan Inter-Professional Collaboration Petugas Puskesmas. Jurnal Kesehatan. 11(1):61-71. 
Dinamika Kesehatan Jurnal Kebidanan dan Keperawatan Vol 11 No. 1 Juli 2020 ( ISSN: 2086-3454 EISSN: 2549-4058)

url: http://ojs.dinamikakesehatan.unism.ac.id DOI : https://doi.org/10.33859/dksm.v11il

Pengendalian Kualitas Kesehatan dalam Upaya Penanggulangan Gizi Buruk pada Balita: Literatur Review

Soetjiningsih. 2000. Pedoman Diagnosis dan

Terapi Ilmu Kesehatan Anak RSUP

Sanglah. Denpasar: SMF Ilmu

Kesehatan Anak FK Unud Denpasar.

Denpasar

Rodriguez et. al. 2008. Outcomes of Interprofessional Collaboration for Hospitalized Cancer Patients. Cancer nursing. 31(2): 18-27

Unicef. 2012. Ringkasan kajian kesehatan ibu dan anak. 